\title{
EFEKTIVITAS PEMBELAJARAN KONTEKSTUAL MODEL PENGAJARAN BERBASIS MASALAH DALAM MENINGKATKAN PRESTASI DAN PENGUASAAN MATERI PELAJARAN IPA
}

\author{
Rastam \\ SDN 6 Wonorejo \\ Email: rastamsdn6wonorejo@gmail.com
}

\begin{abstract}
In order to learn something well, we need to listen, see, ask questions about it, and discuss it with others. Not only that, students need to "do it", that is, describe things in their own way, show examples, try to practice skills and do assignments that demand the knowledge they have acquired. This research uses classroom action research in three cycles. Each cycle consists of four stages, namely: Planning, Acting, Observing, and Reflecting. The subject of this research is the fifth grade students of SDN 6 Wonorejo for the 2018/2019 academic year. The data obtained are in the form of formative test results, observation sheets for teaching and learning activities. From the results of the analysis, it was found that student learning achievement had increased from cycle I to cycle III, namely, cycle I (64.00\%), cycle II (76.00\%), cycle III (88.00\%). The conclusion from this research is that problem-based contextual learning can have a positive effect on the learning motivation of Class V SDN 6 Wonorejo students in the 2018/2019 academic year, and this learning model can be used as an alternative to learning science.
\end{abstract}

Keywords: Science Lessons, Contextual, Problem Base

\section{PENDAHULUAN}

Pembangunan Nasional di bidang pengembangan sumberdaya manusia Indonesia yang berkualitas melalui pendidikan merupakan upaya yang sungguh-sungguh dan terus-menerus dilakukan untuk mewujudkan manusia Indonesia seutuhnya. Sumberdaya yang berkualitas akan menentukan mutu kehidupan pribadi, masyarakat, dan bangsa dalam rangka mengantisipasi, mengatasi persoalan-persoalan, dan tantangan-tantangan yang terjadi dalam masyarakat pada kini dan masa depan.

Salah satu permasalahan yang dihadapi oleh bangsa Indonesia adalah rendahnya mutu pendidikan, khususnya pendidikan dasar dan menengah. Berbagai usaha telah dilakukan untuk menigkatkan mutu pendidikan nasional, antara lain melalui berbagai pelatihan dan peningkatan kualitas guru, penyempurnaan kurikulum, pengadaan buku dan alat pelajaran, perbaikan sarana dan prasarana pendidikan lain, dan peningkatan mutu manajemen sekolah, namun demikian, berbagai indikator mutu pendidikan belum menunjukkan peningkatan yang memadai.

Upaya peningkatan kualitas pendidikan di Indonesia tidak pernah berhenti. Berbagai terobosan baru terus dilakukan oleh pemerintah melalui Depdiknas. Upaya itu antara lain dalam pengelolaan sekolah, peningkatan sumber daya tenaga pendidikan, pengembangan/penulisan materi ajar, serta pengembangan paradigma baru dengan metodologi pengajaran.

Mengajar bukan semata persoalan menceritakan. Belajar bukanlah konsekuensi otomatis dari perenungan informasi ke dalam benak siswa. Belajar memerlukan keterlibatan mental dan kerja siswa sendiri. Penjelasan dan pemeragaan semata tidak akan membuahkan hasil belajar yang langgeng. Yang bisa membuahkan hasil belajar yang langgeng hanyalah kegiatan belajar aktif.

Apa yang menjadikan belajar aktif? Agar belajar menjadi aktif siswa harus mengerjakan banyak sekali tugas. Mereka harus menggunakan otak, mengkaji gagasan, memecahkan masalah, dan menerapkan apa yang mereka pelajari. Belajar akif harus gesit, menyenangkan, bersemangat dan penuh gairah. Siswa bahkan sering meninggalkan tempat duduk mereka, bergerak leluasa dan berfikir keras (moving about dan thinking aloud)

Untuk bisa mempelajari sesuatu dengan baik, kita perlu mendengar, melihat, mengajukan 
pertanyaan tentangnya, dan membahasnya dengan orang lain. Bukan Cuma itu, siswa perlu "mengerjakannya", yakni menggambarkan sesuatu dengan cara mereka sendiri, menunjukkan contohnya, mencoba mempraktekkan keterampilan, dan mengerjakan tugas yang menuntut pengetahuan yang telah atau harus mereka dapatkan.

Dengan menyadari gejala-gejala atau kenyataan tersebut diatas, maka dalam penelitian ini penulis penulis mengambil judul "Efektivitas Pembelajaran Kontekstual Model Pengajaran Berbasis Masalah Dalam Meningkatkan Prestasi dan Penguasaan Materi Pelajaran IPA Pada Siswa Kelas V SDN 6 Wonorejo Tahun Pelajaran 2018/2019"

Bertitik tolak dari latar belakang diatas maka penulis merumuskan permasalahnnya sebagi berikut : (1) Bagaimanakah peningkatan prestasi dan penguasaan materi pelajaran IPA dengan diterapkannya metode pembelajaran kontektual model pembelajarn berbasis masalah pada siswa Kelas V SDN 6 Wonorejo Tahun Pelajaran 2018/2019? (2) Bagaimanakah pengaruh pembelajaran kontekstual model pengajaran berbasis masalah dalam membantu siswa meningkatkan pemahaman dan motivasi belajar IPA pada siswa Kelas V SDN 6 Wonorejo Tahun Pelajaran 2018/2019?

Sesuai dengan permasalahan di atas, penelitian ini bertujuan untuk: (1) Ingin mengetahui bagaimana prestasi, pemahaman dan penguasaan mata pelajaran IPA setelah diterapkannya pembelajaran kontekstual model pengajaran berbasis masalah pada siswa Kelas V SDN 6 Wonorejo Tahun Pelajaran 2018/2019. Mengetahui pengaruhnya metode pembelajaran kontekstual model pengajaran berbasis masalah dalam meningkatkan prestasi dan pemahaman siswa terhadap materi pelajaran IPA setelah diterapkan pembelajaran kontekstual model pengajaran berbasis masalah pada siswa Kelas V SDN 6 Wonorejo Tahun Pelajaran 2018/2019.

Berdasarkan pada permasalahan dalam penelitian tindakan yang berjudul Efektivitas Pembelajaran Kontekstual Model Pengajaran Berbasis Masalah Dalam Meningkatkan Prestasi dan Penguasaan Materi Pelajaran IPA Pada Siswa Kelas V SDN 6 Wonorejo Tahun Pelajaran 2018/2019 yang dilakukan oleh peneliti, dapat dirumuskan hipotesis tindakan sebagai berikut: "Jika Proses Belajar Mengajar Siswa Kelas V SDN 6 Wonorejo Tahun Pelajaran 2018/2019 dalam menyampaikan materi pembelajaran, maka dimungkinkan minat belajar dan hasil belajar siswa kelas V SDN 6 Wonorejo Tahun Pelajaran 2018/2019 akan lebih baik dibandingkan dengan proses belajar mengajar yang dilakukan oleh guru sebelumnya".

Pengertian belajar sudah banyak dikemukakan dalam kepustakaan. Yang dimaksud belajar yaitu perbuatan murid dalam bidang material, formal serta fungsional pada umumnya dan bidang intelektual pada khususnya. Jadi belajar merupakan hal yang pokok. Belajar merupakan suatu perubahan pada sikap dan tingkah laku yang lebih baik, tetapi kemungkinan mengarah pada tingkah laku yang lebih buruk.

Jadi prestasi adalah hasil yang telah dicapai oleh karena itu semua individu dengan adanya belajar hasilnya dapat dicapai. Setiap individu belajar menginginkan hasil yang yang sebaik mungkin. Oleh karena itu setiap individu harus belajar dengan sebaik-baiknya supaya prestasinya berhasil dengan baik. Sedang pengertian prestasi juga ada yang mengatakan prestasi adalah kemampuan. Kemampuan di sini berarti yan dimampui individu dalam mengerjakan sesuatu.

Untuk memperoleh prestasi/hasil belajar yang baik harus dilakukan dengan baik dan pedoman cara yang tapat. Setiap orang mempunyai cara atau pedoman sendiri-sendiri dalam belajar. Pedoman/cara yang satu cocok digunakan oleh seorang siswa, tetapi mungkin kurang sesuai untuk anak/siswa yang lain. Hal ini disebabkan karena mempunyai perbedaan individu dalam hal kemampuan, kecepatan dan kepekaan dalam menerima materi pelajaran.

Faktor-faktor Yang Mempengaruhi Belajar : (1) Faktor yang ada pada diri siswa itu sendiri yang kita sebut faktor individu. Yang termasuk ke dalam faktor individu antara lain faktor kematangan atau pertumbuhan, kecerdasan, latihan, motivasi, dan faktor pribadi. (2) Faktor yang ada pada luar individu yang kita sebut dengan faktor social. Sedangkan yang faktor sosial antara lain faktor keluarga, keadaan rumah tangga, guru, dan cara dalam mengajarnya, lingkungan dan kesempatan yang ada atau tersedia dan motivasi sosial.

Berdasarkan faktor yang mempengaruhi kegiatan belajar di atas menunjukkan bahwa belajar itu merupaka proses yang cukup kompleks. Artinya pelaksanaan dan hasilnya sangat ditentukan oleh faktor-faktor di atas. Bagi siswa yang berada dalam faktor yang mendukung kegiatan belajar akan dapat 
dilalui dengan lancar dn pada gilirannya akan memperoleh prestasi atau hasil belajar yang baik.

Sebaliknya bagi siswa yang berada dalam kondisi belajar yang tidak menguntungkan, dalam arti tidak ditunjang atau didukung oleh faktor-faktor diatas, maka kegiatan atau proses belajarnya akan terhambat atau menemui kesulitan.

IPA didefiniksan sebagai suatu kumpulan pengetahuan yang tersusun secara alam. Perkembangan IPA tidak hanya ditandai dengan adanya fakta, tetapi juga oleh adanya metode ilmiah dan sikap ilmiah. Metode ilmiah dan pengamatan ilmiah menekankan pada hakikat IPA.

Dari penjelasan di atas, dapat disimpulkan bahwa hakikat IPA merupakan bagian dari IPA, dimana konsep-konsepnya diperoleh melalui suatu proses dengan menggunakan metode ilmiah dan diawali dengan sikap ilmiah kemudian diperoleh hasil (produk).

Proses dalam pengertian disini merupakan interaksi semua komponen atau unsur yang terdapat dalam belajar mengajar yang satu sama lainnya saling berhubungan (inter independent) dalam ikatan untuk mencapai tujuan (Usman, 2000: 5).

Belajar diartikan sebagai proses perubahan tingkah laku pada diri individu berkat adanya interaksi antara individu dengan lingkungannya. Hal ini sesuai dengan yang diutarakan Burton bahwa seseorang setelah mengalami proses belajar akan mengalami perubahan tingkah laku, baik aspek pengetahuannya, keterampilannya, maupun aspek sikapnya. Misalnya dari tidak bisa menjadi bisa, dari tidak mengerti menjadi mengerti. (dalam Usman, 2000: 5).

Mengajar merupakan suatu perbuatan yang memerlukan tanggungjawab moral yang cukup berat. Mengajar pada prinsipnya membimbing siswa dalam kegiatan suatu usaha mengorganisasi lingkungan dalam hubungannya dengan anak didik dan bahan pengajaran yang menimbulkan proses belajar.

Proses belajar mengajar merupakan suatu inti dari proses pendidikan secara keseluruhan dengan guru sebagai pemegangn peran utama. Proses belajar mengajar merupakan suatu proses yang mengandung serangkaian perbuatan guru dan siswa atas dasar hubungan timbal balik yang berlangsung dalam situasi edukatif untuk mencapai tujuan tertentu. Interaksi atau hubungan timbal balik antara guru dan siswa itu merupakan syarat utama bagi berlangsungnya proses belajar mengajar (Usman, 2000: 4).
Sedangkan menurut buku Pedoman Guru Pendidikan Agama Islam, proses belajar mengajar dapat mengandung dua pengertian, yaitu rentetan kegiatan perencanaan oleh guru, pelaksanaan kegiatan sampai evaluasi program tindak lanjut (dalam Suryabrata, 1997: 18).

Dari kedua pendapat tersebut dapat disimpulkan bahwa proses belajar mengajar IPA meliputi kegiatan yang dilakukan guru mulai dari perencanaan, pelaksanaan kegiatan sampai evaluasi dan program tindak lanjut yang berlangsung dalam situasi edukatif untuk mencapai tujuan tertentu yaitu pengajaran IPA.

Belajar dapat membawa suatu perubahan pada individu yang belajar. Perubahan ini merupakan pengalaman tingkah laku dari yang kurang baik menjadi lebih baik. Pengalaman dalam belajar merupakan pengalaman yang dituju pada hasil yang akan dicapai siswa dalam proses belajar di sekolah. Menurut Poerwodarminto (1991: 768), prestasi belajar adalah hasil yang dicapai (dilakukan, dekerjakan), dalam hal ini prestasi belajar merupakan hasil pekerjaan, hasil penciptaan oleh seseorang yang diperoleh dengan ketelitian kerja serta perjuangan yang membutuhkan pikiran.

Berdasarkan uraian diatas dapat dikatakan bahwa prestasi belajar yang dicapai oleh siswa dengan melibatkan seluruh potensi yang dimilikinya setelah siswa itu melakukan kegiatan belajar. Pencapaian hasil belajar tersebut dapat diketahui dengan megadakan penilaian tes hasil belajar. Penilaian diadakan untuk mengetahui sejauh mana siswa telah berhasil mengikuti pelajaran yang diberikan oleh guru. Di samping itu guru dapat mengetahui sejauh mana keberhasilan guru dalam proses belajar mengajar di sekolah.

Sejalan dengan prestasi belajar, maka dapt diartikan bahwa prestasi belajar IPA adalah nilai yang dipreoleh siswa setelah melibatkan secara langsung/aktif seluruh potensi yang dimilikinya baik aspek kognitif (pengetahuan), afektif (sikap) dan psikomotor (keterampilan) dalam proses belajar mengajar IPA.

Kalangan pendidik telah menyadari bahwa peserta didik memiliki bermacam cara belajar. Sebagian siswa bisa belajar dengan sangat baik hanya dengan melihat orang lain melakukannya. Biasanya, mereka ini menyukai penyajian informasi yang runtut. Mereka lebih suka menuliskan apa yang dikatakan guru. Selama pelajaran, mereka biasanya diam dan jarang terganggu oleh kebisingan. Perserta didik visual ini berbeda dengan 
peserta didik auditori, yang biasanya tidak sungkansungkan untuk memperhatikan apa yang dikerjakan oleh guru, dan membuat catatan. Mereka menggurulkan kemampuan untuk mendengar dan mengingat. Selama pelajaran, mereka mungkin banyak bicara dan mudah teralihkan perhatiannya oleh suara atau kebisingan. Peserta didik kinestetik belajar terutama dengan terlibat langsung dalam kegiatan. Mereka cenderung impulsive, semau gue, dan kurang sabaran. Selama pelajaran, mereka mungkin saja gelisah bila tidak bisa leluasa bergerak dan mengerjakan sesuatu. Cara mereka belajar boleh jadi tampak sembarangan dan tida karuan.

Pengajaran berbasis masalah (Problem-Based Learning) adalah suatu pandekatan pengajaran yang menggunakan masalah dunia nyata sebagai suatu konteks bagi siswa untuk belajar tentang cara berpikir kritis dan keterampilan pemecahan masalah, serta untuk memperoleh pengetahuan dan konsep yang esensial dari materi pelajaran.

Pengajaran masalah digunakan untuk merangsang berpikir tingkat tinggi dalam situasi berorientasi masalah, termasuk di dalamnya belajar bagaimana belajar. Menurut Ibrahim dan Nur (200: 2)), "Pengajaran berbasis masalah dikenal dengan nama lain seperti Project-Based Teacihg (Pembelajaran Proyek), Experienced-Based Education (Pendidikan berdasarkan pengalaman), Authentic Learning (Pembelajaran Autentik), dan Achoered Instruction (Pembelajaran berakar pada kehidupan nyata)".

Peran guru dalam pengajaran berbasis masalah adalah menyajikan masalah, mengajukan pertanyaan, dan memfasilitasi penyelidikan dan dialog. Pengajaran berbasis masalah tidak dapat dilaksanakan tanpa guru mengembangkan lingkungan kelas yang memungkinkan terjadinya pertukaran ide secara terbuka. Secara garis besar pengajaran berbasis masalah terdiri dari menyajikan kepada siswa situasi masalah yang autentik dan bermakna yang dapat memberikan kemudahan kepada mereka untuk melakukan penyelidikan dan ikuiri.

Pengajaran berbasis masalah dicirikan oleh siswa bekerja sama satu sama lain (paling sering secara berpasangan atau dalam kelompok kecil). Bekerja sama memberikan motivasi untuk secara berkelanjutan terlibat dalam tugas-tugas kompleks dan memperbanyak peluang untuk berbagi inkuiri dan dialog dan untuk mengembangkan keterampilan sosial dan keterampilan berpikir.
Pengajaran berbasis masalah dirancang untuk membantu guru memberikan informasi sebanyakbanyaknya kepada siswa. Pengajaran berbasis masalah dikembangkan terutama untuk membantu siswa mengembangkan kemampuan berpikir, pemecahan masalah, dan keterampilan intelektual, belajar tentang berbagai peran orang dewasa melalui pelibatan mereka dalam pengalaman nyata atau simulasi, dan menjadikan pembelajar yang otonom dan mandiri. Uraian rinci terhdap ketiga tujuan itu dijelaskan lebih jauh oleh Ibrahim dan Nur (2000:7-12) berikut ini.

Berbagai macam ide telah digunakan untuk menggambarkan cara seseorang berpikir. Tetapi, apakah sebenarnya yang terlibat dalam proses berpikir? Apakah keterampilan berpikir itu dan terutama apakah keterampilan berpikir itu? (1) Berpikir adalah proses yang melibatkan operasi mental seperti induksi, deduksi, klasifikasi, dan penalaran. (2) Berpikir adalah proses secara simbolik menyatakan (melalui bahasa) objek nyata dan kejadian-kejadian dan penggunaan pernyataan simbolik itu untuk menemuan prinsip-prinsip esensial tentang objek dan kejadian itu untuk menemukan prinsip-prinsip esensial tentang objek dan kejadian itu. Pernyataan simbolik (abstrak) seperti itu biasanya berbeda dengan operasi mental yang didasarkan pada tingkat konkret dari fakta dan kasus khusus. (3) Berpikir adalah kemampuan untuk menganalisis, mengkritik, dan mencapai kesimpulan berdasar pada inferensi atau pertimbangan yang seksama.

Resnick juga memberikan rasional tentang bagaimana pengajaran berbasis masalah membantu siswa untuk berkinerja dalam situasi kehidupan nyata dan belajar tentang pentingnya peran orang dewasa. Dalam banyak hal pengajaran berbasis masalah bersesuaian dengan aktivitas mental di luar sekolah sebagaimana yang diperankan oleh orang dewasa.

Pengajaran berbasis masalah memiliki unsurunsur belajar magang. Hal tersebut mendorong pengamatan dan dialog dengan orang lain, sehingga secara bertahap siswa dapat memahami peran penting dari aktivitas mental dan belajar yang terjadi di luar sekolah.

Pengajaran berbasis masalah melibatkan siswa dalam penyelidikan pilihan sendiri, yang memungkinkan siswa menginterpretasikan dan menjelaskan fenomena dunia nyata dan membangun pemahamannya tentang fenomena tersebut. 


\section{METODE PENELITIAN}

Penelitian ini merupakan penelitian tindakan (action research), karena penelitian dilakukan untuk memecahkan masalah pembelajaran di kelas. Penelitian ini juga termasuk penelitian deskriptif, sebab menggambarkan bagaimana suatu teknik pembelajaran diterapkan dan bagaimana hasil yang diinginkan dapat dicapai.

Menurut Oja dan Sumarjan (dalam Titik Sugiarti, 1997: 8) mengelompokkan penelitian tindakan menjadi empat macam yaitu, (a) guru sebagai penelitia; (b) penelitian tindakan kolaboratif; (c) simultan terintegratif; (d) administrasi social eksperimental.

Dalam penelitian tindakan ini menggunakan bentuk guru sebagai peneliti, penanggung jawab penuh penelitian ini adalah guru. Tujuan utama dari penelitian tindakan ini adalah untuk meningkatkan hasil pembelajaran di kelas dimana guru secara penuh terlibat dalam penelitian mulai dari perencanaan, tindakan, pengamatan, dan refleksi.

Dalam penelitian ini peneliti tidak bekerjasama dengan siapapun, kehadiran peneliti sebagai guru di kelas sebagai pengajar tetap dan dilakukan seperti biasa, sehingga siswa tidak tahu kalau diteliti. Dengan cara ini diharapkan didapatkan data yang seobjektif mungkin demi kevalidan data yang diperlukan.

Tempat penelitian adalah tempat yang digunakan dalam melakukan penelitian untuk memperoleh data yang diinginkan. Penelitian ini bertempat di Kelas V SDN 6 Wonorejo Tahun Pelajaran 2018/2019.

Waktu penelitian adalah waktu berlangsungnya penelitian atau saat penelitian ini dilangsungkan. Penelitian ini dilaksanakan pada bulan September sampai dengan November semester gasal tahun pelajaran 2018/2019.

Subyek penelitian adalah siswa-siswi Kelas V SDN 6 Wonorejo Tahun Pelajaran 2018/2019.

Penelitian ini menggunakan Penelitian Tindakan Kelas (PTK). Menurut Tim Pelatih Proyek PGSM, PTK adalah suatu bentuk kajian yang bersifat reflektif oleh pelaku tindakan yang dilakukan untuk meningkatkan kemantapan rasional dari tindakan mereka dalam melaksanakan tugas, memperdalam pemahaman terhadap tindakantindakan yang dilakukan itu, serta memperbaiki kondisi dimana praktek pembelajaran tersebut dilakukan (dalam Mukhlis, 2003: 3).

Sedangkah menurut Mukhlis (2003: 5) PTK adalah suatu bentuk kajian yang bersifat sistematis reflektif oleh pelaku tindakan untuk memperbaiki kondisi pembelajaran yang dilakukan.

Adapun tujuan utama dari PTK adalah untuk memperbaiki/meningkatkan pratek pembelajaran secara berkesinambungan, sedangkan tujuan penyertaannya adalah menumbuhkan budaya meneliti di kalangan guru (Mukhlis, 2003: 5).

Sesuai dengan jenis penelitian yang dipilih, yaitu penelitian tindakan, maka penelitian ini menggunakan model penelitian tindakan dari Kemmis dan Taggart (dalam Sugiarti, 1997: 6), yaitu berbentuk spiral dari sklus yang satu ke siklus yang berikutnya. Setiap siklus meliputi planning (rencana), action (tindakan), observation (pengamatan), dan reflection (refleksi). Langkah pada siklus berikutnya adalah perncanaan yang sudah direvisi, tindakan, pengamatan, dan refleksi. Sebelum masuk pada siklus 1 dilakukan tindakan pendahuluan yang berupa identifikasi permasalahan.

Instrumen yang digunakan dalam penelitian ini terdiri dari: (1) Silabus. Yaitu seperangkat rencana dan pengaturan tentang kegiatan pembelajaran pengelolahan kelas, serta penilaian hasil belajar. (2) Rencana Pelajaran (RP). Yaitu merupakan perangkat pembelajaran yang digunakan sebagai pedoman guru dalam mengajar dan disusun untuk tiap putaran. Masing-masing RP berisi kompetensi dasar, indikator pencapaian hasil belajar, tujuan pembelajaran khusus, dan kegiatan belajar mengajar. (3) Tes formatif. Tes ini disusun berdasarkan tujuan pembelajaran yang akan dicapai, digunakan untuk mengukur kemampuan pemahaman konsep IPA pokok. Tes formatif ini diberikan setiap akhir putaran. Bentuk soal yang diberikan adalah pilihan guru (objektif).

Data-data yang diperlukan dalam penelitian ini diperoleh melalui observasi pengolahan metode pembelajaran kontekstual model pengajaran berbasis masalah, dan tes formatif.

Untuk mengetahui keefektivan suatu metode dalam kegiatan pembelajaran perlu diadakan analisa data. Pada penelitian ini menggunakan teknik analisis deskriptif kualitatif, yaitu suatu metode penelitian yang bersifat menggambarkan kenyataan atau fakta sesuai dengan data yang diperoleh dengan tujuan untuk mengetahui prestasi belajar yang dicapai siswa juga untuk memperoleh respon siswa terhadap kegiatan pembelajaran serta aktivitas siswa selama proses pembelajaran.

Untuk mengalisis tingkat keberhasilan atau persentase keberhasilan siswa setelah proses belajar 
mengajar setiap putarannya dilakukan dengan cara memberikan evaluasi berupa soal tes tertulis pada setiap akhir putaran.

\section{HASIL DAN PEMBAHASAN PENELITIAN Siklus I}

Tahap Perencanaan. Pada tahap ini peneliti mempersiapkan perangkat pembelajaran yang terdiri dari rencana pelajaran 1 , soal tes formatif 1 dan alat-alat pengajaran yang mendukung.

Tahap Kegiatan dan Pelaksanaan. Pelaksanaan kegiatan belajar mengajar untuk siklus I dilaksanakan pada tanggal 4 September 2018 di
Kelas V SDN 6 Wonorejo Tahun Pelajaran 2018/2019 dengan jumlah siswa 25 siswa. Dalam hal ini peneliti bertindak sebagai guru. Adapun proses belajar mengajar mengacu pada rencana pelajaran yang telah dipersiapkan. Pengamatan (observasi) dilaksanakan bersamaan dengan pelaksaaan belajar mengajar

Pada akhir proses belajar mengajar siswa diberi tes formatif I dengan tujuan untuk mengetahui tingkat keberhasilan siswa dalam proses belajar mengajar yang telah dilakukan. Adapun data hasil penelitian pada siklus I adalah sebagai berikut:

Table 1. Nilai Tes Formatif Pada Siklus I

\begin{tabular}{|c|c|c|c|c|c|c|c|}
\hline \multirow{2}{*}{ No. Urut } & \multirow{2}{*}{ Nilai } & \multicolumn{2}{|c|}{ Keterangan } & \multirow{2}{*}{ No. Urut } & \multirow{2}{*}{ Nilai } & \multicolumn{2}{|c|}{ Keterangan } \\
\hline & & $\mathbf{T}$ & TT & & & $\mathbf{T}$ & TT \\
\hline 1 & 40 & & $\sqrt{ }$ & 14 & 50 & & $\sqrt{ }$ \\
\hline 2 & 70 & $\sqrt{ }$ & & 15 & 30 & & $\sqrt{ }$ \\
\hline 3 & 80 & $\sqrt{ }$ & & 16 & 60 & & $\sqrt{ }$ \\
\hline 4 & 50 & & $\sqrt{ }$ & 17 & 80 & $\sqrt{ }$ & \\
\hline 5 & 70 & $\sqrt{ }$ & & 18 & 40 & & $\sqrt{ }$ \\
\hline 6 & 80 & $\sqrt{ }$ & & 19 & 80 & $\sqrt{ }$ & \\
\hline 7 & 70 & $\sqrt{ }$ & & 20 & 60 & & $\sqrt{ }$ \\
\hline 8 & 60 & & $\sqrt{ }$ & 21 & 70 & $\sqrt{ }$ & \\
\hline 9 & 80 & $\sqrt{ }$ & & 22 & 80 & $\sqrt{ }$ & \\
\hline 10 & 80 & $\sqrt{ }$ & & 23 & 80 & $\sqrt{ }$ & \\
\hline 11 & 70 & $\sqrt{ }$ & & 24 & 50 & & $\sqrt{ }$ \\
\hline 12 & 70 & $\sqrt{ }$ & & 25 & 80 & $\sqrt{ }$ & \\
\hline 13 & 80 & $\sqrt{ }$ & & Jumlah & 760 & 6 & 6 \\
\hline Jumlah & 900 & 10 & 3 & & & & \\
\hline
\end{tabular}

Jumlah Skor 1660

Jumlah Skor Maksimal Ideal 2500

$\%$ Skor Tercapai 66,40

Keterangan: $\mathrm{T}$

TT

Jumlah siswa yang tuntas

Jumlah siswa yang belum tuntas

Klasikal
: Tuntas

: Tidak Tuntas

$: 16$

$: 9$

: Belum tuntas

Tabel 2. Rekapitulasi Hasil Tes Formatif Siswa pada Siklus I

\begin{tabular}{clc}
\hline No & \multicolumn{1}{c}{ Uraian } & Hasil Siklus I \\
\hline 1 & Nilai rata-rata tes formatif & 66,40 \\
2 & Jumlah siswa yang tuntas belajar & 16 \\
3 & Persentase ketuntasan belajar & 64,00
\end{tabular}

Dari tabel di atas dapat dijelaskan bahwa dengan menerapkan pembelajaran kontekstual model pengajaran berbasis masalah diperoleh nilai rata-rata prestasi belajar siswa adalah 66,40 dan ketuntasan belajar mencapai $64,00 \%$ atau ada 16 siswa dari 25 siswa sudah tuntas belajar. Hasil 
tersebut menunjukkan bahwa pada siklus pertama secara klasikal siswa belum tuntas belajar, karena siswa yang memperoleh nilai $\geq 65$ hanya sebesar $64,00 \%$ lebih kecil dari persentase ketuntasan yang dikehendaki yaitu sebesar $85 \%$. Hal ini disebabkan karena siswa masih asing dengan diterapkannya pembelajaran kontekstual model pengajaran berbasis masalah.

Siklus II

Tahap perencanaan. Pada tahap ini peneliti mempersiapkan perangkat pembelajaran yang terdiri dari rencana pelajaran 2, soal tes formatif II dan alat-alat pengajaran yang mendukung.

Tahap kegiatan dan pelaksanaan. Pelaksanaan kegiatan belajar mengajar untuk siklus II dilaksanakan pada tanggal 11 Oktober 2018 di
Kelas V SDN 6 Wonorejo Tahun Pelajaran 2018/2019 dengan jumlah siswa 25 siswa. Dalam hal ini peneliti bertindak sebagai guru. Adapun proses belajar mengajar mengacu pada rencana pelajaran dengan memperhatikan revisi pada siklus I, sehingga kesalah atau kekurangan pada siklus I tidak terulanga lagi pada siklus II. Pengamatan (observasi) dilaksanakan bersamaan dengan pelaksanaan belajar mengajar.

Pada akhir proses belajar mengajar siswa diberi tes formatif II dengan tujuan untuk mengetahui tingkat keberhasilan siswa dalam proses belajar mengajar yang telah dilakukan. Instrument yang digunakan adalah tes formatif II. Adapun data hasil penelitian pada siklus II adalah sebagai berikut.

Table 3. Nilai Tes Formatif Pada Siklus II

\begin{tabular}{|c|c|c|c|c|c|c|c|}
\hline \multirow{2}{*}{ No. Urut } & \multirow{2}{*}{ Nilai } & \multicolumn{2}{|c|}{ Keterangan } & \multirow{2}{*}{ No. Urut } & \multirow{2}{*}{ Nilai } & \multicolumn{2}{|c|}{ Keterangan } \\
\hline & & $\mathbf{T}$ & TT & & & $\mathbf{T}$ & TT \\
\hline 1 & 70 & $\sqrt{ }$ & & 14 & 70 & $\sqrt{ }$ & \\
\hline 2 & 80 & $\sqrt{ }$ & & 15 & 60 & & $\sqrt{ }$ \\
\hline 3 & 90 & $\sqrt{ }$ & & 16 & 80 & $\sqrt{ }$ & \\
\hline 4 & 50 & & $\sqrt{ }$ & 17 & 80 & $\sqrt{ }$ & \\
\hline 5 & 70 & $\sqrt{ }$ & & 18 & 70 & $\sqrt{ }$ & \\
\hline 6 & 80 & $\sqrt{ }$ & & 19 & 70 & $\sqrt{ }$ & \\
\hline 7 & 70 & $\sqrt{ }$ & & 20 & 60 & & $\sqrt{ }$ \\
\hline 8 & 60 & & $\sqrt{ }$ & 21 & 80 & $\sqrt{ }$ & \\
\hline 9 & 70 & $\sqrt{ }$ & & 22 & 80 & $\sqrt{ }$ & \\
\hline 10 & 80 & $\sqrt{ }$ & & 23 & 60 & & $\sqrt{ }$ \\
\hline 11 & 80 & $\sqrt{ }$ & & 24 & 70 & $\sqrt{ }$ & \\
\hline 12 & 50 & & $\sqrt{ }$ & 25 & 80 & $\sqrt{ }$ & \\
\hline 13 & 70 & $\sqrt{ }$ & & Jumlah & 860 & 9 & 3 \\
\hline Jumlah & 920 & 10 & 3 & & & & \\
\hline
\end{tabular}

Jumlah Skor 1780

Jumlah Skor Maksimal Ideal 2500

$\%$ Skor Tercapai 71,20

\begin{tabular}{|c|c|c|c|c|}
\hline Keterangan & : & $\begin{array}{l}\text { T } \\
\text { TT } \\
\text { Jumlah siswa yang tuntas } \\
\text { Jumlah siswa yang belum tuntas } \\
\text { Klasikal }\end{array}$ & $\begin{array}{l}: \text { Tuntas } \\
: \text { Tidak Tuntas } \\
: 19 \\
: 6 \\
: \text { Belum tuntas }\end{array}$ & \\
\hline \multicolumn{5}{|c|}{ Tabel 4. Hasil Tes Formatif Siswa pada Siklus II } \\
\hline No & \multicolumn{3}{|c|}{ Uraian } & Hasil Siklus II \\
\hline 1 & \multicolumn{3}{|c|}{ Nilai rata-rata tes formatif } & 71,20 \\
\hline 2 & \multicolumn{3}{|c|}{ Jumlah siswa yang tuntas belajar } & 19 \\
\hline 3 & \multicolumn{3}{|c|}{ Persentase ketuntasan belajar } & 76,00 \\
\hline
\end{tabular}

Dari tabel di atas diperoleh nilai rata-rata prestasi belajar siswa adalah 71,20 dan ketuntasan belajar mencapai 76,00\% atau ada 19 siswa dari 25 siswa sudah tuntas belajar. Hasil ini menunjukkan 
bahwa pada siklus II ini ketuntasan belajar secara klasikal telah mengalami peningkatan sedikit lebih baik dari siklus I. Adanya peningkatan hasil belajar siswa ini karena siswa sudah mulai akrab dan menemuan keasyikan dengan metode pembelajaran kontekstual model pengajaran berbasis masalah. Disamping itu kemampuan guru dalam mengelola proses belajar mengajar dalam metode ini juga semakin meningkat sehingga proses belalarmengajar semakin efektif.

Siklus III

Tahap Perencanaan. Pada tahap ini peneliti mempersiapkan perangkat pembelajaran yang terdiri dari rencana pelajaran 3 , soal tes formatif 3 dan alat-alat pengajaran yang mendukung.

Tahap kegiatan dan pengamatan. Pelaksanaan kegiatan belajar mengajar untuk siklus III dilaksanakan pada tanggal 18 Oktober 2018 di Kelas V SDN 6 Wonorejo Tahun Pelajaran 2018/2019 dengan jumlah siswa 25 siswa. Dalam hal ini peneliti bertindak sebagai guru. Adapun proses belajar mengajar mengacu pada rencana pelajaran dengan memperhatikan revisi pada siklus II, sehingga kesalahan atau kekurangan pada siklus II tidak terulang lagi pada siklus III. Pengamatan (observasi) dilaksanakan bersamaan dengan pelaksanaan belajar mengajar.

Pada akhir proses belajar mengajar siswa diberi tes formatif III dengan tujuan untuk mengetahui tingkat keberhasilan siswa dalam proses belajar mengajar yang telah dilakukan. Instrumen yang digunakan adalah tes formatif III. Adapun data hasil penelitian pada siklus III adalah sebagai berikut:

Table 5. Nilai Tes Formatif pada Siklus III

\begin{tabular}{|c|c|c|c|c|c|c|c|}
\hline \multirow{2}{*}{ No. Urut } & \multirow{2}{*}{ Nilai } & \multicolumn{2}{|c|}{ Keterangan } & \multirow{2}{*}{ No. Urut } & \multirow{2}{*}{ Nilai } & \multicolumn{2}{|c|}{ Keterangan } \\
\hline & & $\mathbf{T}$ & TT & & & $\mathbf{T}$ & TT \\
\hline 1 & 70 & $\sqrt{ }$ & & 14 & 80 & $\sqrt{ }$ & \\
\hline 2 & 80 & $\sqrt{ }$ & & 15 & 90 & $\sqrt{ }$ & \\
\hline 3 & 80 & $\sqrt{ }$ & & 16 & 80 & $\sqrt{ }$ & \\
\hline 4 & 70 & $\sqrt{ }$ & & 17 & 70 & $\sqrt{ }$ & \\
\hline 5 & 70 & $\sqrt{ }$ & & 18 & 80 & $\sqrt{ }$ & \\
\hline 6 & 90 & $\sqrt{ }$ & & 19 & 60 & & $\sqrt{ }$ \\
\hline 7 & 80 & $\sqrt{ }$ & & 20 & 80 & $\sqrt{ }$ & \\
\hline 8 & 60 & & $\sqrt{ }$ & 21 & 90 & $\sqrt{ }$ & \\
\hline 9 & 80 & $\sqrt{ }$ & & 22 & 80 & $\sqrt{ }$ & \\
\hline 10 & 90 & $\sqrt{ }$ & & 23 & 70 & $\sqrt{ }$ & \\
\hline 11 & 70 & $\sqrt{ }$ & & 24 & 80 & $\sqrt{ }$ & \\
\hline 12 & 80 & $\sqrt{ }$ & & 25 & 60 & & $\sqrt{ }$ \\
\hline 13 & 90 & $\sqrt{ }$ & & Jumlah & 920 & 10 & 2 \\
\hline Jumlah & 1010 & 12 & 1 & & & & \\
\hline
\end{tabular}

Jumlah Skor 1930

Jumlah Skor Maksimal Ideal 2500

$\%$ Skor Tercapai 77,20

$\begin{array}{lll}\text { Keterangan } \quad: \quad \mathrm{T} & : \text { Tuntas } \\ \text { TT } & : \text { Tidak Tuntas } \\ & \text { Jumlah siswa yang tuntas } & : 22 \\ \text { Jumlah siswa yang belum tuntas } & : 3 \\ \text { Klasikal } & : \text { Tuntas }\end{array}$

Tabel 6. Hasil Tes Formatif Siswa pada Siklus III

\begin{tabular}{clc}
\hline No & \multicolumn{1}{c}{ Uraian } & Hasil Siklus III \\
\hline 1 & Nilai rata-rata tes formatif & 77,20 \\
2 & Jumlah siswa yang tuntas belajar & 22 \\
\hline
\end{tabular}


Berdasarkan tabel diatas diperoleh nilai ratarata tes formatif sebesar 77,20 dan dari 25 siswa yang telah tuntas sebanyak 22 siswa dan 3 siswa belum mencapai ketuntasan belajar. Maka secara klasikal ketuntasan belajar yang telah tercapai sebesar $88,00 \%$ (termasuk kategori tuntas). Hasil pada siklus III ini mengalami peningkatan lebih baik dari siklus II. Adanya peningkatan hasil belajar pada siklus III ini dipengaruhi oleh adanya peningkatan kemampuan siswa mempelajari materi pelajaran yang telah diterapkan selama ini. Disamping itu dengan adanya metode pembelajaran ini siswa dapat bertanya dengan sesama temanya, dan ternyata dari proses bertanya antar siswa ini, siswa lebih mudah menerima penjelasan dari temannya yang lebih paham tengtang materi pelejaran tersebut. Juga dari hasil pembelajaran kontekstual model pengajaran berbasis masalah ini murid jadi lebih mudah untuk bekerja sama dengan sesama temanya.

Pada tahap ini akah dikaji apa yang telah terlaksana dengan baik maupun yang masih kurang baik dalam proses belajar mengajar dengan penerapan metode pembelajaran kontekstual model pengajaran berbasis masalah. Dari data-data yang telah diperoleh dapat duraikan sebagai berikut: (1) Selama proses belajar mengajar guru telah melaksanakan semua pembelajaran dengan baik. Meskipun ada beberapa aspek yang belum sempurna, tetapi persentase pelaksanaannya untuk masing-masing aspek cukup besar. (2) Berdasarkan data hasil pengamatan diketahui bahwa siswa aktif selama proses belajar berlangsung. (3) Kekurangan pada siklus-siklus sebelumnya sudah mengalami perbaikan dan peningkatan sehingga menjadi lebih baik. (4) Hasil belajar siswsa pada siklus III mencapai ketuntasan.

Pada siklus III guru telah menerapkan metode pembelajaran kontekstual model pengajaran berbasis masalah dengan baik dan dilihat dari aktivitas siswa serta hasil belajar siswa pelaksanaan proses belajar mengajar sudah berjalan dengan baik. Maka tidak diperlukan revisi terlalu banyak, tetapi yang perlu diperhatikan untuk tindakah selanjutnya adalah memaksimalkan dan mempertahankan apa yang telah ada dengan tujuan agar pada pelaksanaan proses belajar mengajar selanjutnya penerapan metode pembelajaran kontekstual model pengajaran berbasis masalah dapat meningkatkan proses belajar mengajar sehingga tujuan pembelajaran dapat tercapai.

\section{Pembahasan}

Ketuntasan Hasil belajar Siswa. Melalui hasil peneilitian ini menunjukkan bahwa pembelajaran kontekstual model pengajaran berbasis masalah memiliki dampak positif dalam meningkatkan daya ingat siswa. Hal ini dapat dilihat dari semakin mantapnya pemahaman dan penguasaan siswa terhadap materi yang telah disampaikan guru selama ini (ketuntasan belajar meningkat dari sklus I, II, dan III) yaitu masing-masing 64,00\%, 76,00\%, dan $88,00 \%$. Pada siklus III ketuntasan belajar siswa secara klasikal telah tercapai.

Kemampuan Guru dalam Mengelola Pembelajaran. Berdasarkan analisis data, diperoleh aktivitas siswa dalam proses pembelajaran kontekstual model pengajaran berbasis masalah dalam setiap siklus mengalami peningkatan. Hal ini berdampak positif terhadap proses mengingat kembali materi pelajaran yang telah diterima selama ini, yaitu dapat ditunjukkan dengan meningkatnya nilai rata-rata siswa pada setiap siklus yang terus mengalami peningkatan.

Aktivitas Guru dan Siswa Dalam Pembelajaran. Berdasarkan analisis data, diperoleh aktivitas siswa dalam proses pembelajaran IPA dengan pembelajaran kontekstual model pengajaran berbasis masalah yang paling dominan adalah bekerja dengan menggunakan alat/media, mendengarkan/memperhatikan penjelasan guru, dan diskusi antar siswa/antara siswa dengan guru. Jadi dapat dikatakan bahwa aktivitas isiwa dapat dikategorikan aktif.

Sedangkan untuk aktivitas guru selama pembelajaran telah melaksanakan langkah-langkah metode pembelajaran kontekstual model pengajaran berbasis masalahdengan baik. Hal ini terlihat dari aktivitas guru yang muncul di antaranya aktivitas membimbing dan mengamati siswa dalam mengerjakan kegiatan, menjelaskan/melatih menggunakan alat, memberi umpan balik/evaluasi/tanya jawab dimana prosentase untuk aktivitas di atas cukup besar.

\section{SIMPULAN DAN SARAN Simpulan}

Dari hasil kegiatan pembelajaran yang telah dilakukan selama tiga siklus, dan berdasarkan 
seluruh pembahasan serta analisis yang telah dilakukan dapat disimpulkan sebagai berikut: (1) Pembelajaran dengan pembelajaran kontekstual model pengajaran berbasis masalah memiliki dampak positif dalam meningkatkan prestasi belajar siswa yang ditandai dengan peningkatan ketuntasan belajar siswa dalam setiap siklus, yaitu siklus I $(64,00 \%)$, siklus II $(76,00 \%)$, siklus III $(88,00 \%)$.

(2) Penerapan pembelajaran kontekstual model pengajaran berbasis masalah mempunyai pengaruh positif, yaitu dapat meningkatkan motivasi belajar siswa untuk mempelajari materi pelajaran yang diterima selama ini, dimana hal tersebut ditunjukan dengan rata-rata sikap siswa yang menyatakan bahwa siswa tertarik dan berminat dengan pembelajaran kontekstual model pengajaran berbasis masalah sehingga mereka menjadi termotivasi untuk belajar. (3) Pembelajaran kontekstual model pengajaran berbasis masalah memiliki dampak positif terhadap pemahaman materi pelajaran yang diajaran, dimana dengan metode ini siswa dipaksa untuk memecahkan masalah yang beruhubungan dengan materi palajaran yang diajarkan.

\section{Saran}

Dari hasil penelitian yang diperoleh dari uraian sebelumnya agar proses belajar mengajar IPA lebih efektif dan lebih memberikan hasil yang optimal bagi siswa, maka disampaikan saran sebagai berikut: (1) Untuk melaksanakan metode pembelajaran kontekstual model pengajaran berbasis masalah memerlukan persiapan yang cukup matang, sehingga guru harus mempu menentukan atau memilih topik yang benar-benar bisa diterapkan dengan pembelajaran kontekstual model pengajaran berbasis masalah dalam proses belajar mengajar sehingga diperoleh hasil yang optimal. (2) Dalam rangka meningkatkan prestasi belajar siswa, guru hendaknya lebih sering melatih siswa dengan berbagai metode pengajaran yang sesuai, walau dalam taraf yang sederhana, dimana siswa nantinya dapat menemuan pengetahuan baru, memperoleh konsep dan keterampilan, sehingga siswa berhasil atau mampu memecahkan masalahmasalah yang dihadapinya.

\section{DAFTAR PUSTAKA}

Arikunto, Suharsimi. ..... Prosedur Penelitian Suatu Pendekatan Praktek. Jakarta: Rineksa Cipta

Ali, Muhammad. 1996. Guru Dalam Proses Belajar Mengajar. Bandung: Sinar Baru Algesindon.

Daroeso, Bambang. 1989. Dasar dan Konsep Pendidikan Moral Pancasila. Semarang: Aneka Ilmu.

Dayan, Anto. 1972. Pengantar Metode Statistik Deskriptif, tt. Lembaga Penelitian Pendidian dan Penerangan Ekonomi.

Hadi, Sutrisno. 198. Metodologi Research, Jilid 1. Yogyakarta: YP. Fak. Psikologi UGM.

Melvin, L. Siberman. 2004. Aktif Learning, 101 Cara Belajar Siswa Aktif. Bandung: Nusamedia dan Nuansa.

Ngalim, Purwanto M. 1990. Psikologi Pendidikan. Bandung: PT. Remaja Rosdakarya.

Riduwan. 2000. Belajar Mudah Penelitian untuk Guru-Karyawan dan Peneliti Pemula. Bandung: Alfabeta.

Sukmadinata, Nana Syaodih. 2000. Metode Penelitian Pendidikan. Bandung: PT. Remaja Rosdakarya.

Surakhmad, Winarno. 1990. Metode Pengajaran Nasional. Bandung: Jemmars 